\title{
Effects of reactive oxygen species on skin photoaging
}

\author{
Wpływ reaktywnych form tlenu na proces fotostarzenia skóry
}

\author{
Anna M. Augustyniak', Helena Rotsztejn', Ewelina Bartnicka², Elżbieta Budzisz²
}

'Department of Cosmetology and Aesthetic Dermatology, Faculty of Pharmacy, Medical University of Lodz 2Department of Cosmetic Raw Materials Chemistry, Faculty of Pharmacy, Medical University of Lodz

KEY WORDS:

reactive oxygen species, antioxidant, photoaging.

SŁOWA KLUCZOWE:

reaktywne formy tlenu, antyoksydanty, fotostarzenie.

ADDRESS FOR CORRESPONDENCE:

Anna M. Augustyniak

Department of Cosmetology

and Aesthetic Dermatology

Faculty of Pharmacy

Medical University of Lodz

1 Muszyńskiego St

91-151 Lodz, Poland

Phone: +48 426779315

e-mail: anna.maria.augustyniak

@umed.lodz.pl

\begin{abstract}
The large surface area of the skin, high metabolism and location at the border of two environments (external and internal) cause continuous production of free radicals within the skin. There are two mechanisms of skin photoaging. The first one involves UVA-induced production of reactive oxygen species. The second mechanism is based on a direct interaction of UVB with DNA and induction of damage in the DNA structure. One way by which UVA leads to skin aging is activation of the AP-1 transcription factor due to singlet oxygen, which is released by UV radiation. Antioxidants slow down oxidation leading to the formation of free radicals, or inactivate already formed free radicals, and thereby accelerate interruption of chain reactions. Moreover, photoprotection has a key role in combating photoaging and eliminating its effects.
\end{abstract}

\section{STRESZCZENIE}

Duża powierzchnia skóry, wysoki metabolizm oraz usytuowanie na granicy dwóch środowisk (zewnętrznego i wewnętrznego) sprawiają, że w jej obrębie nieustannie dochodzi do produkcji wolnych rodników. Istnieją dwa mechanizmy fotostarzenia skóry. Pierwszy polega na produkowaniu reaktywnych form tlenu pod wpływem UVA, które następnie wpływają na cząsteczki skóry i powodują dalsze przemiany. Drugi mechanizm opiera się na bezpośredniej interakcji promieniowania UVB z DNA i indukowaniu uszkodzeń DNA. Promieniowanie UVA prowadzi do procesu starzenia się skóry, między innymi w drodze aktywacji czynnika transkrypcyjnego AP-1, poprzez uwalniany pod wpływem UV tlen singletowy. Antyoksydanty spowalniają procesy utleniania skutkujące powstaniem wolnych rodników lub dezaktywują już wytworzone, przez co przyspieszają przerwanie reakcji łańcuchowych. Ważną rolę w walce $\mathrm{z}$ fotostarzeniem skóry odgrywa fotoprotekcja wraz z niwelowaniem jego skutków.

\section{INTRODUCTION}

Photoaging is one of the processes in which reactive oxygen species take part. In photoaging the stratum corneum may undergo hyperkeratosis, and the epidermis is dry, flaky and usually thickened. There are wrinkles, creases, hyperpigmentation, telangiectasia, sagging skin, milia and solar blackheads. Clinically, photoaging may include solar keratosis, basal cell carcinoma, squamous-cell carcinoma and melanoma. 
Histological changes in the epidermis include modifications in its thickness and variations in the morphology of epidermal cells. Melanocytes are damaged and their proliferation, hyperplasia and dysplasia increase. Changes are also observed in the morphology of Langerhans cells, followed by impairment of their activity and reduction of their number. The basement membrane, which separates the epidermis from the dermis, becomes overgrown. A characteristic feature of photoaging within the dermis is elastosis, or accumulation of abnormal masses of elastin. This leads to degradation of fibrillin (proteins responsible for cross-linking of elastin fibers) and formation of dense clusters of elastin in the dermis. The structure of collagen fibers undergoes changes and the amount of collagen type I decreases. Increased numbers of proteoglycans and glycosaminoglycans and inflammatory cells such as mast cells, eosinophils, and granulocytes are observed. Also, microcirculatory and angiogenesis disturbances arise, leading to telangiectasia [1].

Ultraviolet radiation can cause huge changes in the structure and appearance of the skin. It consists of three wavelength ranges: UVC (100-290 nm), which is absorbed by the ozone layer, UVB (290$320 \mathrm{~nm}$ ) which is responsible for skin burns, and UVA (320-400 nm), which causes immediate discoloration and delayed skin reactions. UVB radiation is mostly absorbed by skin $(90 \%$ of the radiation of this wavelength range is stopped by the stratum corneum), and thus it mainly affects epidermal cells. UVA radiation reaches deeper layers of the skin and may affect both the epidermis and the dermis. More than $50 \%$ of UVA radiation penetrates papillary and reticular layers of the dermis $[1,2]$.

\section{FREE RADICAL THEORY OF AGING}

The large surface area of the skin, high metabolism and location at the border of two environments (external and internal) cause continuous production of free radicals within the skin. According to free radical theory, aging is a result of irreversible damage to tissue cells caused by free radicals. Furthermore, aging leads to accumulation of changes in mitochondrial DNA and RNA, which interferes with proper activity in the respiratory chain, which then leads to a further production of reactive oxygen species (ROS) and increased mutagenesis of mDNA. This phenomenon increase the changes in mitochondria, in their components and functions. Defects in mitochondrial DNA and malfunctioning of the respiratory chain lead to decreased production of ATP in a cell, the consequence of which is insufficient energy demand. According to this concept, ROS are the main cause of inactivation and destruction of mitochondria [3,4].
The molecular mechanism which induced premature skin aging by tobacco smoke was compared to the effect of solar radiation on the skin. One of the ways by which UVA leads to skin aging is activation of AP-1 transcription factor due to singlet oxygen, which is released by UV radiation. It was shown that tobacco-induced increased expression of nuclear matrix protein (NMP) might be related to the effects of free radicals. Ascorbic acid and vitamin E (having an ability to capture and inactivate ROS), which were added to the culture of human fibroblasts exposed to tobacco smoke, inhibited production of metalloproteinases. Furthermore, the role of oxidative stress in the aging process has been confirmed by numerous studies showing that free radicals may be responsible for the destruction of DNA and RNA of cell membranes $[5,6]$.

\section{THE ROLE OF REACTIVE OXYGEN SPECIES IN PHOTOAGING}

There are two mechanisms of skin photoaging. The first one involves UVA-induced production of reactive oxygen species. These in turn affect skin molecules and cause further changes. The second mechanism is based on direct interaction of UVB with DNA and induction of damage in the DNA structure.

Reactive oxygen species participating in skin photoaging are: superoxide anions, peroxides and singlet oxygen, and their number significantly increases after exposure of the skin to UV and normalizes after the exposure ceases. Tests in vivo showed an increase in the level of hydrogen peroxide after 15-minute exposure of the skin to UVA/UVB at doses lower than the minimum erythema dose (MED) $[1,7]$. The ROS activate nuclear factor $(\mathrm{NF})-\kappa \mathrm{B}$, which influences the expression of cytokines on the surface of keratinocytes and dermal cells. The most important cytokines in this process include interleukin 1 (IL-1), epidermal growth factor (EGF) and tumor necrosis factor $\alpha$ (TNF- $\alpha)$. These cytokines stimulate mitogenactivated protein kinases (MAPK), which affect the expression of activator protein 1 (AP-1) transcription factor. Then, under the influence of AP-1, the expression of metalloproteinases (MMP) is observed, and this results in proteolysis of extracellular matrix proteins, particularly procollagen type I and III. At the same time the synthesis of new collagen is reduced due to inhibition of transforming growth factor $\beta$ (TGF- $\beta$ ). The described changes result in reducing skin integrity as well as the effectiveness of regeneration mechanisms (Figure 1) [1].

Skin which is chronically exposed to UV radiation exhibits a higher level of mutation of mitochondrial DNA (mDNA) than protected skin, and reactive oxygen species are responsible for these changes. It was 


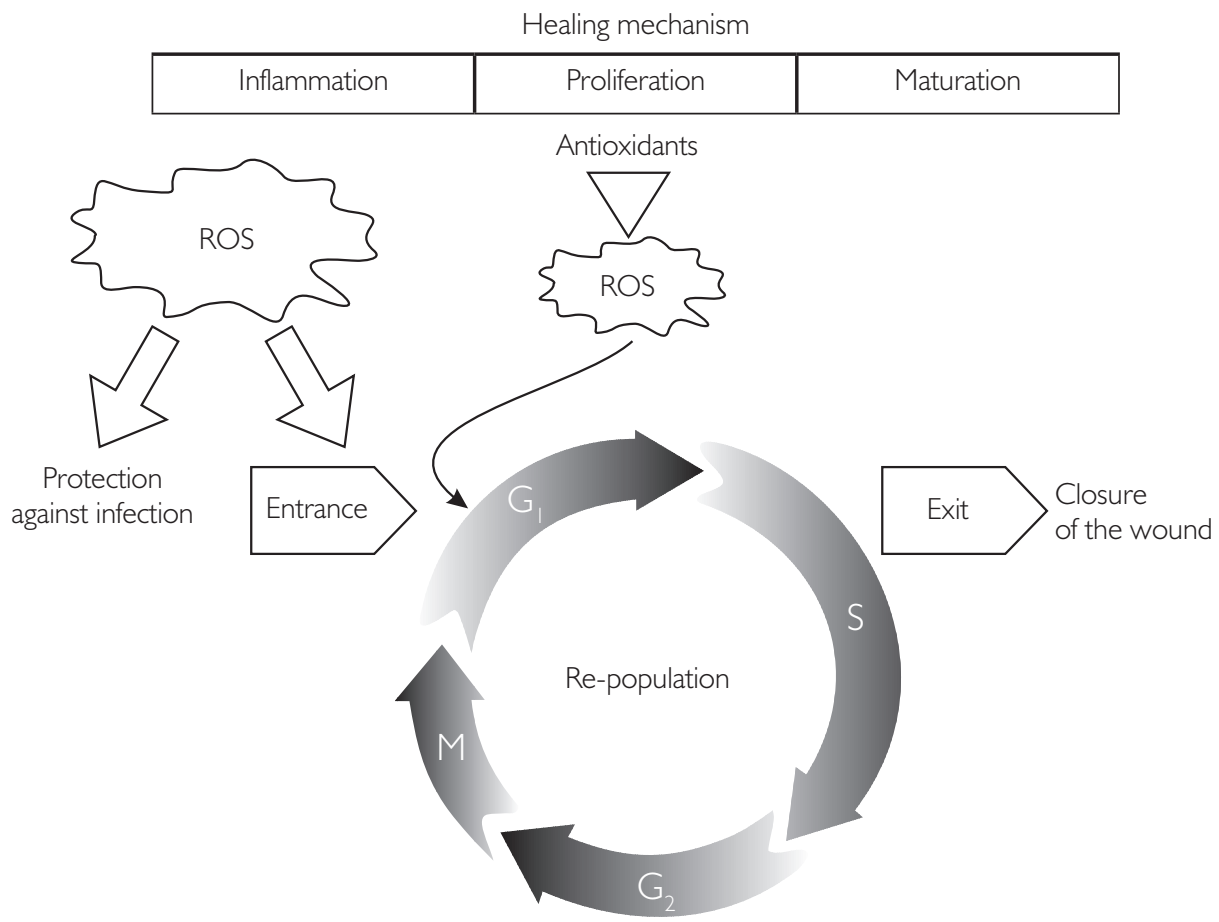

Figure I. Role of reactive oxygen species in healing process (Adapted from: E.H. Sarsour et al. Redox control of the cell cycle in health and disease. Antioxid Redox Signal 2009, II, 2985-30 I I)

Rycina I. Rola wolnych rodników tlenowych w procesach gojenia (zaadaptowane z E.H. Sarsour i inni. Redox control of the cell cycle in health and disease. Antioxid Redox Signal 2009, II, 2985-30 II)

noted in in vitro tests that deletions of mDNA disappear after UV exposure, whereas in in vivo tests they are present for four months after irradiation [8].

DNA damage caused by ROS generates formation of pyrimidine dimers (e.g. thymine dimers) on the strand of DNA and damage to guanine nucleotide, which in turn leads to shortening of telomeres at the end of the chromosome. Gradual shortening of telomeres during cell division is responsible for chronological aging, but UV radiation may also contribute to this effect.

Additionally, UV radiation induces angiogenesis through activation of the vascular endothelial growth factor (VEGF) and inhibition of protein, which is a potent inhibitor of angiogenesis. The newly formed vessels are highly permeable, allowing penetration of inflammation mediators, e.g. IL-8, and causing inflammation in the skin. This increases degradation of the extracellular matrix and reduces the number of vessels in the dermis. It is also worth mentioning that UV radiation can directly cause immunosuppression, leading to ontogenesis and to aggravated symptoms of infectious diseases [8].

Exposure to pro-oxidative elements leads to the production of reactive oxygen species and bioactive molecules in the skin, which may damage the cells. Changes in the skin, damaging its function as a barrier, involve mainly stratum corneum lipids and corneocyte proteins. They are observed in many skin diseases, e.g. psoriasis, contact dermatitis, atopic dermatitis and carcinogenesis, as well as in skin aging, photoaging and chronoaging [9]. The structure of the stratum corneum lipids has a crucial role in maintaining the integrity of the epidermal barrier. A lack of unsaturated fatty acids, cholesterol or ceramides results in increased transepidermal water loss. A defective epidermal barrier induces regeneration mechanisms and triggers a proinflammatory response. In order to restore the integrity of the barrier, DNA synthesis of epidermal cells and release of Odland lamellar bodies are activated. Moreover, the destruction of the barrier stimulates production of IL-1 $\alpha$, TNF cytokines and granulocyte-macrophage colony stimulating factor (GM-CSF) [10]. Enzymatic and non-enzymatic skin antioxidants are responsible for preventing oxidative damage to lipids and structural proteins [11]. Excessive exposure to harmful external factors may lead to oxidative imbalance in the skin and immunity deficiencies, which results in damage of its components. The content of antioxidant in the skin increases with the number of layers, that is, the minimum concentration is observed in superficial layers (stratum corneum), and it is significantly higher in layers located deeper. This phenomenon can be explained by the fact that corneocytes of the stratum corneum tend to exfoliate and they are constantly be- 
ing replaced with new cells. Additionally, the stratum corneum, as the top layer of the skin, is exposed to contact with oxidants much more frequently than lower layers. The skin lipid layer contains more antioxidants ( $\alpha$ - and $\gamma$-tocopherols) compared to the stratum corneum, which is caused by secretion of vitamin E through sebaceous glands. Finally, corneocytes slough off, removing other antioxidants and their reaction products from the body [12].

\section{SKIN DEFENSE AGAINST REACTIVE OXYGEN SPECIES - ANTIOXIDANTS}

Antioxidants slow down oxidation, leading to the formation of free radicals or inactivate already formed free radicals, and thereby accelerate interruption of chain reactions. Antioxidants can act in different ways: lower oxygen consumption, prevent initiation of lipid peroxidation by neutralization of free radicals, bind the metal ions $\mathrm{Fe}^{2+}$ and $\mathrm{Cu}^{2+}$, thereby inhibiting initiation of the Fenton reaction, change peroxyl radicals in non-radical products, e.g. alcohols, break the chain of lipid peroxidation, or neutralize indirect radicals. Endogenous free radical systems of the skin mainly include superoxide dismutase (SOD), catalase (CAT), thioredoxin reductase (TR) and peroxidase and glutathione reductase (GPx and GR). Exposure to sunlight disturbs the relative proportions of CAT and SOD within the stratum corneum, which may cause increased susceptibility to oxidative damage. Moreover, this indicates that there are periodic fluctuations of CAT activity within the stratum corneum. The observed enzyme activity is low in summer and higher in winter. Superoxide dismutase is not subject to such fluctuations. Some non-enzymatic proteins also have the ability to capture free radicals, e.g. ceruloplasmin, albumin, metallothionein, transferrin and haptoglobin. Metallothioneins ensure proper homeostasis of metals such as zinc and copper, by storing them. The antioxidant effect of metallothionein also involves rapid reaction with free radicals due to the presence of numerous sulfhydryl groups. Their increased synthesis is observed in response to stress hormones, cytokines and heavy metals. Transition metals such as selenium and zinc play a crucial role in removing free radicals and their effects. Zinc is an important component of the antioxidant defense system. Moreover, zinc ions are a component of zinc-copper superoxide dismutase. This metal also causes induction of metallothioneins - proteins that have the ability to remove oxidants. It also removes metals such as copper and iron from their membrane binding sites, protecting cell membranes against peroxidation. Zinc inhibits formation of the hydroxyl radical from hydrogen peroxide. Moreover, it shows a synergistic effect with vitamin E or polyphenols. Deficiency of this element directly and indirectly affects elements of the antioxidant system. Selenium is an essential component of key antioxidants (glutathione peroxidase and thioredoxin reductase). Proteins containing selenium are antioxidants that inhibit, inter alia, lipid peroxidation and DNA and RNA damage (protection against genetic damage and deformation) [13]. Other roles of selenium are also connected with induction and activation of the endogenous antioxidant system.

Small molecule non-enzymatic antioxidants include vitamin E, vitamin C, vitamin A (retinol) and $\beta$-carotene (provitamin A), coenzyme $Q$, flavonoids, and lipoic acid. Due to their preventive and therapeutic effects, these compounds are used in cosmetic products, especially with anti-aging effects. Vitamin $\mathrm{E}$ is a hydrophobic substance, and its action is mostly limited to cell membranes. One of the important characteristics of vitamin $\mathrm{E}$ as an antioxidant is pro-oxidative stabilization of the structure of cell membranes and a direct influence on the activity of certain enzymes. Vitamin E is also a powerful factor in reducing the oxidation-reduction potential of cells and the first line of defense against free oxygen radicals in the aquatic environment. Vitamin $C$ prevents peroxidation processes initiated by free radicals, neutralizes free radicals created by the activation of neutrophils, and suppresses the release of superoxide anions by macrophages. Vitamin $\mathrm{C}$ and glutathione have a protective function for mitochondria. Ascorbic acid, when applied topically, improves the appearance of photoaged skin, protects and reduces the amount of damage caused by UVB radiation, and stimulates the synthesis of collagen by fibroblasts. The amount of vitamin $\mathrm{C}$ in the skin drops dramatically after UV irradiation [14]. In contrast, antioxidant properties of vitamin A are rather mild, and in the fight against reactive oxygen species carotenoids, especially $\beta$-carotene, are a more effective weapon. $\beta$-carotene, or provitamin $A$, is an antioxidant that effectively neutralizes singlet oxygen and lipid peroxides [15]. $\beta$-carotene taken orally at high doses (90 mg daily) reduces the sensitivity of the skin to ultraviolet radiation and radiation-induced damage [16]. Topical application of this pro-vitamin prevents some unfavorable changes associated with the oxidative influence of UV (protection against oxidation of lipids and proteins of the skin). Other active antioxidants among carotenoids are lycopene, lutein and astaxanthin. Coenzyme $Q$ has a stabilizing effect on cell membranes, increasing their resistance to noxious agents and avoiding a loss of its integrity. Coenzyme Q, applied to the skin, significantly reduces the effects of aging. Tests carried out on fibroblast cultures confirmed that coenzyme $Q$ has anti-aging 
benefits for human fibroblasts. It protects keratinocytes against UVA radiation and reduces collagenase activity after UVA irradiation [17].

The antioxidant mechanism of flavonoids is based on capturing ROS, reducing ROS generation in cells by inhibiting the activity of enzymes, chelating transition metal ions, breaking the cascade of reactions leading to lipid peroxidation of cells and their organelles, and protection of other small molecule antioxidants against oxidation. Additionally, flavonoids increase the stability of biological membranes, considerably reducing damage caused by oxidizing agents. In the reactions of inactivation of already generated radicals, the reaction of flavonoids with the hydroxyl radical is especially effective [18].

The antioxidant effect of melatonin is complex. The first mechanism is a direct action, resulting in the reaction of melatonin with free radicals and their non-radical derivatives. The direct mechanism is based on synergism with other antioxidants. This hormone exhibits antioxidant properties, participating in the indirect receptor mechanism of free radical scavenging [13]. The antioxidant indirect mechanisms include the ability to stimulate the antioxidant cellular response by the increase in mRNA levels in cells and activation of antioxidant enzymes, e.g. SOD, stimulating the production of low-molecular antioxidants and reducing the formation of new radicals in the respiratory chain in mitochondria [19]. Furthermore, it was shown that melatonin protects the skin against UV rays and in this respect it has synergy with vitamin E. It also inhibits lipid peroxyl radicals and acts synergistically with $\alpha$-tocopherol.

Lipoic acid is considered to be the most active antioxidant because of its properties: good solubility in lipids, water and organic solvents and ability to penetrate cell membranes, which, in combination with low molecular weight $(206.3 \mathrm{~g} / \mathrm{mol})$, provides good absorption through the skin. Experiments on mice have shown that the penetration is very high; the compound penetrates the epidermis and is visible in the dermis and the hypodermis after a few hours.

\section{ANTIOXIDANT EFFECT OF ESTROGEN ON THE SKIN}

The skin is one of the estrogen-dependent organs [20]. Estrogens affect normal hair growth, vascularization, pigmentation, elasticity and ability of the skin to retain water [21]. In the skin there are specific receptors for estrogen [22], which are present in keratinocytes, fibroblasts, sebaceous and sweat glands, hair follicles and vessels. The largest quantity of them is found on the face, which is expressed in characteristic features of aging typical for menopause - in the skin two estrogen receptors, ER- $\alpha$ and ER- $\beta$ [23]. These receptors are proteins encoded by various genes on different chromosomes (ER- $\alpha$ - chromosome 6; ER- $\beta$ - chromosome 14). Studies using immunohistochemical methods in biopsies of the skin and skin thickness measured by ultrasound confirm reduction of the number of collagen fibers during menopause. Beneficial effects of estrogen on the skin were tested on large population groups. The NHANES survey (National Health and Nutrition Examination Survey), conducted in the US on 3,825 women, showed that persons who have been using hormone replacement therapy (HRT) for a very long time had 1/3 fewer wrinkles than women from the control group [24]. Possibly the core of many effects of estrogens is their antioxidant mechanism [25]. Estrogens used in hormone replacement therapy reduce the harmful effects of free radicals, cause cleavage of disulfide bonds in proteins (denaturation), and thus change the activity of some enzymes [26]. Antioxidative effects of HRT depend on the period of its application. The longer it is, the greater is inhibition of free radicals. Antioxidant properties of estrogen result from the specific chemical structure of these compounds. The hydroxy groups, which are bonded with an aromatic ring of estrogens, exhibit properties of phenols and can react with free oxygen species. The reaction produces phenoxy radicals, which have negligible peroxide activity and can be easily reduced by other antioxidants together with regeneration of the initial structure of estrogen. Thus, estrogens and their metabolites are potent antioxidants. Although many studies confirm the antioxidant effect of estrogens, this issue is still controversial, and the molecular mechanism has not been fully explained [27].

\section{PHOTOPROTECTION AS A REMEDY AGAINST PHOTOAGING}

Photoprotection has a key role in combating photoaging and eliminating its effects and can be a natural phenomenon or can be artificially induced.

One of the natural sunscreen mechanisms is melanin - a brown-black eumelanin present in the skin which has the ability to absorb solar radiation (UVA, UVB and visible light). Another mechanism is biosynthesis of urocanic acid, which is formed as a result of proteolytic cleavage of filaggrin and has the ability to absorb UVB radiation. The natural mechanism is also a characteristic structure of the epidermis with keratinization of the stratum corneum, where hyperkeratosis is increased by exposure to UV radiation. The thickened stratum corneum disperses solar radiation and protects the skin against harmful factors.

Artificial defense mechanisms include appropriate clothing - the best protection is provided by 
tightly woven, thick and waterproof materials in dark colors. Protective clothing is very important: hats, face shields, goggles, sunglasses and screens, which protect exposed skin [28-30]. An important element in the prevention of photoaging is sunscreens. Active ingredients of sun protection products can be divided into two groups according to their mechanism of action: chemical filters (organic) which absorb photons of UV radiation and physical filters which reflect and disperse ultraviolet rays. It is recommended that sunscreen products have a wide spectrum of action (against UVA and UVB), and a high sun protection factor (SPF) of 30 or higher. The quantity of an applied sunscreen product is also very important; the recommended dose is $2 \mathrm{mg} / \mathrm{cm}^{2}$ of skin. Additionally, sunscreen should be applied to the skin within 15-30 min before exposure to the sun and added every 2-3 h, especially after swimming or intense sweating. Another way of photoprotection is avoiding exposure to the sun in the period of strongest radiation, that is, between 10 a.m. and 4 p.m. in summer, as well as not using tanning salons [1].

\section{CONCLUSIONS}

It is clear that reactive oxygen species have an extremely significant impact on the process of photoaging of the skin. They contribute to the lots of unfavorable changes in the skin, and deactivation of free radicals can be an important element in fighting against these negative processes.

\section{ACKNOWLEDGMENTS}

Thank you very much Mrs. Natalia Maślińska for help in preparing the manuscript.

This work was supported by Grant No. 503/3-06602/503-31-001 and 500/3-066-01/503-31-001 from the Medical University of Lodz, Poland.

\section{CONFLICT OF INTEREST}

The authors report no conflicts of interest.

\section{References}

1. Poon F., Kang S., Chien A.L.: Mechanisms and treatments of photoaging. Photodermatol Photoimmunol Photomed 2015, 31, 65-74.

2. Kang S., Chung J.H., Lee J.H., Fisher G.J., Wan Y.S., Duell E.A. et al: Topical N-acetyl cysteine and genistein prevent ultraviolet-light-induced signaling that leads to photoaging in human skin in vivo. J Invest Dermatol 2003, 120, 835-841.

3. Ivanova D.G., Yankova T.M.: The free radical theory of aging in search of a strategy for increasing life span. Folia Medica 2013, 55, 33-41.

4. Piotrowska A., Bartnik E.: Rola reaktywnych form tlenu i mitochondriów w starzeniu. Post Biochem 2014, 60, 240-247.
5. Yin L., Morrita A., Tsuji T.: Alterations of extracellular matrix included by tobacco smoke extract. Arch Dermatol Res 2000, 292, 188-194.

6. Wojas-Pelc A., Sułowicz J., Nastałek M.: Ultraviolet radiation, tobacco smoke and estrogens pathways of influence on skin aging; capabilities of prevention. Przegl Lek 2008, 65, 862-865.

7. Kang S., Chung J.H., Lee J.H., Fisher G.J., Wan Y.S., Duell E.A., et al.: Topical $\mathrm{N}$-acetyl cysteine and genistein prevent ultraviolet-light-induced signaling that leads to photoaging in human skin in vivo. J Invest Dermatol 2003, 120, 835-841.

8. Berneburg M., Plettenberg H., Krutmann J.: Photoaging of human skin. Photodermatol Photoimmunol Photomed 2000, 16, 239-244.

9. Valacchi G., Sticozzi C., Pecorelli A., Cervellati F., Cervellati C., Maioli E.: Cutaneous responses to environmental stressors. Ann NY Acad Sci 2012, 1271, 75-81.

10. Weber S.U., Han N., Packer L.: Ozone: an emerging oxidative stressor to skin. Curr Probl Dermatol 2001, 29, 52-61.

11. Thiele J.J., Schroeter C., Hsieh S.N., Podda M., Packer L.: The antioxidant network of the stratum corneum. Oxidants and Antioxidants in Cutaneus Biology 2001, 29, 26-42.

12. Valacchi G., Fortino V., Bocci B.: The dual action of ozone on the skin. Br J Dermatol 2005, 153, 1096-1100.

13. Gałecka E., Mrowicka M., Malinowska K., Gałecki P.: Chosen non-enzymatic substances that participate in a protection against overproduction of free radicals. Pol Merkur Lekarski 2008, 25, 269-271.

14. Stojiljković D., Pavlović D., Arsić I.: Oxidative stress, skin aging and antioxidant therapy. Acta Facultatis Medicae Naissensis 2014, 31, 207-217.

15. Augustyniak A., Skrzydlewska E.: Antioxidative abilities during aging. Post Hig Med Dośw 2004, 58, 194-201.

16. Cho S., Lee D.H., Won C.H., Kim S.M., Lee S., Lee M.J., et al.: Differential effects of low-dose and high-dose betacarotene supplementation on the signs of photoaging and type I procollagen gene expression in human skin in vivo. Dermatology 2010, 221, 160-171.

17. Poljsak B., Dahmane R.: Free radicals and extrinsic skin aging. Dermatol Res Pract 2012, 2012, 1-4.

18. Ostrowska J., Skrzydlewska E.: The biological activity of flavonoids. Post Fitoter 2005, 3-4, 71-79.

19. Espino J., Pariente A.J., Rodriguez A.B.: Oxidative stress and immunosenescence: a therapeutic effects of melatonin. Oxid Med Cell Longev 2012, Special section, 1-9.

20. Zegarska B., Woźniak M.: Wpływ estrogenu na zmiany zachodzące w skórze. Przegl Menopauz 2007, 4, 233-238.

21. Pełka M., Broniarczyk-Dyła G.: Wpływ menopauzy na strukturę i procesy fizjologiczne skóry. Przegl Menopauz 2008, 6, 319-321.

22. Trznadel E., Rotsztejn H.: Wpływ hormonów na hamowanie procesu starzenia się skóry. Przegl Menopauz 2007, 6, 381-383.

23. Trznadel E., Rotsztejn H.: Dermatologiczne aspekty menopauzy. Przegl Menopauz 2006, 6, 398-400.

24. Wojas-Pelc A., Nastalek M., Sułowicz J.: Estrogeny a skóra - spowolnienie procesu starzenia. Przegl Menopauz 2008, 6, 314-317.

25. Stetkiewicz T., Pertyński T.: Efekt antoksydacyjny hormonalnej terapii zastępczej. Przegl Ginekol 2000, 1, 63-65.

26. Stetkiewicz T., Jędrzejczyk S., Połać I.: Długość stosowania hormonalnej terapii zastępczej a jej efekt antyoksydacyjny. Przegl Menopauzal 2003, 4, 65-68.

27. Stetkiewicz T., Stachowiak G., Pakalski A.: Kontrowersje wokół antyoksydacyjnego działania estrogenów. Przegl Menopauzal 2006, 6, 343-345. 
28. Moloney N.J., Collins M., Murphy G.M.: Sunscreens: safety, efficacy and appropriate use. Am J Clin Dermatol 2002, 3, 185-191.

29. Palm M.D., O'Donoghue M.N.: Update on photoprotection. Dermatol Ther 2007, 20, 360-376.

Submitted: 13 XII 2015

Accepted: 10 V 2016
30. Wolf R., Matz H., Orion E., Lipozencić J.: Sunscreens - the ultimate cosmetic. Acta Dermatovenerol Croat 2003, 11, 158-162. 